\section{Risk factors for esophageal cancer in non-smokers and non-drinkers: a case-control study in Uruguay}

\section{Fatores de risco para o câncer esofágico em não usuários de tabaco e bebida alcoólica: um estudo caso-controle no Uruguai}

\author{
Alvaro L. Ronco \\ Departamento de Epidemiología \\ Instituto de Radiología y Centro de Lucha Contra el Cáncer \\ Hospital Pereira Rossell \\ Av. Centenario 2995 dep.403, Edif. Treviso \\ Montevideo 11600, Uruguay \\ alronco@redfacil.com.uy \\ Enrique Barrios \\ Departamento de Biofísica \\ Facultad de Medicina, Montevideo, Uruguay \\ Programa de Vigilancia Epidemiológica \\ Comisión Honoraria de Lucha contra el Cáncer, Uruguay \\ Luis Fierro \\ División de Epidemiología y Estadística \\ Instituto Nacional de Oncología, Montevideo, Uruguay \\ Julio Balbi \\ División de Epidemiología y Estadística \\ Instituto Nacional de Oncología, Montevideo, Uruguay \\ María T. Larrinaga \\ División de Epidemiología y Estadística \\ Instituto Nacional de Oncología, Montevideo, Uruguay

\section{Eduardo De Stéfani} \\ Registro Nacional de Cáncer \\ Ministerio de Salud Pública, Montevideo, Uruguay
}

\section{Abstract}

In order to analyze possible associations of lifestyle factors with esophageal cancer among non-smokers and non-drinkers, the authors carried out the present study. Special emphasis was placed on the analysis of "mate" (infusion of the herb Ilex paraguariensis) drinking, which has been associated with most cancers of the upper aerodigestive tract. The study was conducted at the Instituto Nacional de Oncología in Montevideo, Uruguay. Data corresponded to 73 esophageal cancer cases and 219 controls. A detailed questionnaire included sections on sociodemographic variables, occupation, family history of cancer, "mate" drinking, and a restricted list of dietary items including: red meat, processed meat, salted meat, barbecue, milk, fresh vegetables and fruits. Odds ratios (ORs) were estimated by unconditional logistic regression, adjusting for major potential confounders, including age, sex, education, urban/rural status and region of birth. Moderate increases in risk were observed for: daily "mate" consumption $(\mathrm{OR}=2.2)$, age of quitting $(\mathrm{OR}=2.02)$, duration $(\mathrm{OR}=2.49)$ and intensity $(\mathrm{OR}=1.91)$, most of which were statistically significant. Consequently, our report demonstrates a particular role for "mate" consumption on esophageal cancer in Uruguay, regardless of other well-known risk factors.

Key Words: Esophageal cancer. Mate. Ilex paraguariensis. Epidemiology. 
Os autores realizaram o presente estudo para analisar possíveis associações de fatores de estilo de vida com o câncer esofágico em não usuários de tabaco e bebida alcoólica. Foi especialmente enfatizada a análise do "mate" (infusão da erva Ilex paraguariensis), que tem sido associado à maioria dos cânceres do trato aerodigestivo. O estudo foi realizado no Instituto Nacional de Oncología em Montevidéu, Uruguai. Os dados correspondem a 73 casos de câncer esofágico e 219 controles. Um detalhado questionário incluiu seções de variáveis sócio-demográficas, ocupação, história familiar de câncer, consumo de "mate" e uma relação restritiva de itens da dieta incluindo: carne vermelha, carne processada, carne salgada, carne assada, leite, vegetais frescos e frutas. Os odd ratios (ORs) foram estimados com regressão logística incondicional, ajustados segundo os maiores potenciais fatores confundentes, incluindo a idade, o sexo, a educação, o estado urbano/rural e região de nascimento. Observaram-se acréscimos moderados no risco para: consumo diário de "mate" $(\mathrm{OR}=2.2)$, idade de abandono do consumo $(\mathrm{OR}=2.02)$, duração $(\mathrm{OR}=2.49) \mathrm{e}$ intensidade ( $\mathrm{OR}=1.91)$, a maioria dos quais foram estatísticamente significativos. Por conseguinte, nosso informe demonstra um rol particular para o consumo do "mate" no câncer esofágico no Uruguai, independentemente de outros bem conhecidos fatores de risco.

Palavras-chave: Câncer esofágico. Mate. Ilex paraguariensis. Epidemiologia.

\section{Introduction}

Esophageal cancer is a very frequent malignancy among the Uruguayan population, displaying an age-adjusted (world standard population) incidence rate of 12.5 per 100,000 for men $^{1}$, ranking $7^{\text {th }}$ among men ${ }^{2}$.

"Mate", the infusion of the herb Ilex paraguariensis, is a frequently consumed beverage in Uruguay, Argentina, Paraguay, and southern Brazil. A survey carried out in Uruguay showed that the local prevalence of "mate" consumption was $78 \%{ }^{3}$. The survey also found a high correlation between "mate" consumption and smoking. Elevated alcohol consumption, low vegetable and fruit intake and smoking have been thoroughly investigated as factors associated with in-

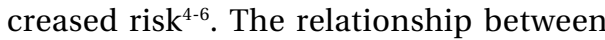
"mate" and esophageal cancer has also been extensively reported ${ }^{4-6}$. Previous reports on "mate" and cancer in humans have showed increased risks for cancer in the esophagus, oropharynx, larynx and bladder ${ }^{5-9}$.

Research on esophageal cancer in nonsmokers and non-drinkers has been particularly scarce ${ }^{10-12}$, and so far there have been no reports on "mate" and esophageal cancer in non-smokers and non-drinkers. Taking into account the above mentioned high correlation between "mate" and tobacco consumption, and considering the difficulties for adequately controlling the confusion between these exposures, we decided to perform the present study excluding smokers and drinkers from the analysis.

\section{Subjects and Methods}

In order to analyze possible associations of lifestyle factors with esophageal cancer among non-smokers and non-drinkers, the authors carried out a study during the period between 1/January/1988 and 18/April/ 2002. Four hundred and sixty-six (466) new cases of esophageal cancer were admitted for treatment at the Instituto Nacional de Oncología in the study period. Three hundred and fifty (350) individuals were interviewed by trained social workers, who were 
blind to major risk factors. No selection of cases was performed. Refusal to answer the questionnaire or severity of illness were the only reasons for not entering the study. All non-smokers and non-drinkers (73 cases, $20.9 \%$ ) from the total were included in the study. Sixty-one cases (83.6\%) were histologically diagnosed with esophageal carcinoma. Of these, 50 cases were squamous cell type, 7 non-specified carcinomas, 2 adenocarcinomas, and 2 were anaplastic types. The remainder (12 cases, $16.4 \%$ ) had an endoscopic diagnostic base. Each case was frequency matched with 3 controls by age (+-5 years) and sex. Controls were randomly selected in each category, from a large database comprising all non-cancer patients and non-melanoma skin cancer patients, the latter usually showing epidemiological similarities with hospital controls. As a result, 219 controls were included in the study. All were patients seeking medical diagnosis and/or treatment at the same hospital during the same time period, and belonged to the same population base, characterized mainly by low income, a low sociocultural level and by being users of the public healthcare system. Conditions for control eligibility were to have a condition other than tobacco-alcohol related malignant tumors or digestive diseases. The distribution of controls is shown in Table 1.

A detailed questionnaire included sections on sociodemographic variables, occupation, family history of cancer, "mate" drinking and a restricted list of dietary items including: red meat, processed meat, salted meat, barbecue, milk, fresh vegetables, and fruits. Particular emphasis was placed on the consumption of "mate", which was measured as liters per day of the infusion, and its duration, intensity (liters per year), age that began drinking "mate" and age that quit drinking it. Answers were open-ended, allowing treatment of each food as a continuous variable ${ }^{13}$. Answers were converted to times per year, multiplying by appropriate time units. All information collected was specifically related to five years before the onset of symptoms of the disease which led to hospital admission.

Non-smokers were defined as individuals who reported that they had never smoked 1 or more cigarettes/day for a continuous period of 1 year or more. Non-drinkers were defined as individuals who had never drank $1 \mathrm{cc}$ per day of ethanol for a continuous period of 1 year or more.

Crude and adjusted Odds ratios (OR), as estimators of the relative risk (RR) for esophageal cancer and the corresponding 95\% confidence interval (CI) were estimated, the latter after adjustment for age (as a continuous variable), sex, education, urban/rural status and region of birth, by the Mantel and Haenszel method ${ }^{14}$. Univariate analyses were performed in order to select relevant variables to be considered for further regression model building. Unconditional multiple logistic regression was subsequently used, fitted by the method of maximum likeli-

Table 1 - Distribution of controls.

Tabla 1 - Distribución de los controles.

\begin{tabular}{lccc}
\hline Anatomic site & ICD-9 & Controls & $\%$ \\
\hline Skin cancer & 173 & 92 & 42.0 \\
Gynecological disorders & $610-629$ & 31 & 14.2 \\
Benign tumors & $210-229$ & 27 & 12.3 \\
Urological diseases & $580-608$ & 14 & 6.4 \\
Dermatological diseases & $680-709$ & 12 & 5.5 \\
Osteoarticular diseases & $710-739$ & 12 & 5.5 \\
Infectious diseases & $001-139$ & 6 & 2.7 \\
Various other diseases & & 19 & 8.7 \\
Healthy controls & & 6 & 2.7 \\
Total & & 219 & 100.0 \\
\hline
\end{tabular}


hood $^{15}$. For multiple levels of exposure, significance was assessed by tests for linear trend in risk ${ }^{15}$. In order to avoid statistical instability, some estimations were performed on a dichotomist basis, using median values as the cut-off point. All calculations were performed with STATA statistical software ${ }^{16}$.

The referred questionnaire has been routinely used for every patient admitted at the Instituto Nacional de Oncología with the approval of the institution's management, since 1988. For this reason, the study did not require the intervention of a Bioethical Committee. Nevertheless, the authors have recently submitted the study to an Ethics Committee at the Uruguayan School of Medicine of the State University, which approved the study design a posteriori. Finally, the authors recognize no interest of conflict related to the present study.

\section{Results}

Table 2 shows the results of the univariate analyses performed on the sociodemographic variables. Females account for 87.7 $\%$. Cases were significantly less educated than controls. Cases and controls also showed significant differences concerning regions of birth and residence. Moreover, rural status seemed to be linked to the disease, but differences were not significant. While region

Table 2 - Distribution of cases and controls according to sociodemographic covariates. Crude Odds Ratios for esophageal cancer estimated after univariate analysis.

Tabla 2 - Distribución de casos y controles según variables sociodemográficas. Odds Ratios crudos para cáncer esofágico estimados luego de análisis univariados.

\begin{tabular}{|c|c|c|c|c|c|c|c|}
\hline Variable & Cases & $\%$ & Controls & $\%$ & $\mathrm{p}$-value & Odds Ratio & $95 \%$ IC \\
\hline \multicolumn{8}{|l|}{ Sex } \\
\hline Male & 9 & 12.3 & 27 & 12.3 & & & \\
\hline Female & 64 & 87.7 & 192 & 87.7 & 1.0 & & \\
\hline \multicolumn{8}{|l|}{ Age } \\
\hline$<60$ & 7 & 9.6 & 21 & 9.6 & & & \\
\hline $60-69$ & 16 & 21.9 & 53 & 24.2 & & & \\
\hline $70-79$ & 33 & 45.2 & 94 & 42.9 & & & \\
\hline$\geq 80$ & 17 & 23.3 & 51 & 23.3 & 0.996 & & \\
\hline \multicolumn{8}{|c|}{ Education (Yrs.) } \\
\hline $0-2$ & 32 & 43.8 & 54 & 24.7 & & 1.00 & \\
\hline $3-4$ & 25 & 34.2 & 69 & 31.5 & & 0.61 & $0.32-1.15$ \\
\hline$\geq 5$ & 16 & 21.9 & 96 & 43.8 & 0.001 & 0.28 & $0.14-0.56$ \\
\hline \multicolumn{8}{|c|}{ Urban/Rural status } \\
\hline Urban & 51 & 69.9 & 172 & 78.5 & & 1.00 & \\
\hline Rural & 22 & 30.1 & 47 & 21.5 & 0.18 & 1.58 & $0.87-2.86$ \\
\hline \multicolumn{8}{|l|}{ Birth region } \\
\hline South & 8 & 11.0 & 75 & 34.2 & & 1.00 & \\
\hline Center & 38 & 52.1 & 94 & 42.9 & & 3.79 & $1.67-8.61$ \\
\hline North & 27 & 37.0 & 50 & 22.8 & 0.0004 & 5.06 & $2.13-12.0$ \\
\hline \multicolumn{8}{|c|}{ Residence region } \\
\hline South & 29 & 39.7 & 127 & 58.0 & & 1.00 & \\
\hline Center & 28 & 38.4 & 73 & 33.3 & & 1.68 & $0.93-3.04$ \\
\hline North & 16 & 21.9 & 19 & 8.7 & 0.003 & 3.69 & $1.69-8.03$ \\
\hline
\end{tabular}


of birth and region of residence displayed positive significant associations, education showed an inverse association with the risk of esophageal cancer.
Table 3 shows the distribution of foods and food groups. There was a significant difference regarding meat consumption between cases and controls $(\mathrm{p}=0.02)$. Salt-cured

Table 3 - Univariate analysis of selected "mate" and dietary covariates.

Tabla 3 - Análisis univariado de variables selectas de "mate" y dietarias.

\begin{tabular}{lccccccc}
\hline Variable & Cases & $\%$ & Controls & $\%$ & $\mathrm{p}$-value & OR & $95 \% \mathrm{Cl}$ \\
\hline $\begin{array}{l}\text { Mate (liters) } \\
\quad 0.49\end{array}$ & 11 & 15.1 & 67 & 30.6 & & 1.00 & \\
$\quad 0.50-0.99$ & 23 & 31.5 & 68 & 31.1 & & 2.06 & $0.93-4.56$ \\
$\quad \geq 1.00$ & 39 & 53.4 & 84 & 38.4 & 0.044 & 2.83 & $1.35-5.94$ \\
& & & & & & & \\
Red meat & 16 & 21.9 & 71 & 32.4 & & 1.00 & \\
$\quad<131$ & 14 & 19.2 & 61 & 27.9 & & 1.02 & $0.46-2.25$ \\
$\quad 131-364$ & 43 & 58.9 & 87 & 39.7 & 0.02 & 2.19 & $1.14-4.22$ \\
$\quad \geq 365$ & & & & & & &
\end{tabular}

\section{Salt-cured meat}

$\begin{array}{llllllll}\text { Never } & 48 & 65.8 & 170 & 77.6 & & 1.00 & \\ 1-65 & 12 & 16.4 & 26 & 11.9 & & 1.63 & 0.77-3.48 \\ \geq 66 & 13 & 17.8 & 23 & 10.5 & 0.12 & 2.00 & 0.94-4.24\end{array}$

\section{Preserved meat}

$\begin{array}{lccccccc}0-11 & 21 & 28.8 & 58 & 26.5 & & 1.00 & \\ 12-51 & 14 & 19.2 & 55 & 25.1 & & 0.70 & 0.33-1.52 \\ \geq 52 & 35 & 47.9 & 89 & 40.6 & & 1.09 & 0.58-2.05 \\ \text { N.A. } & 3 & 4.1 & 17 & 7.8 & 0.44 & & \end{array}$

Milk

$\begin{array}{llllllll}0-364 & 18 & 24.7 & 49 & 22.4 & & 1.00 & \\ 365-727 & 26 & 35.6 & 74 & 33.8 & & 0.96 & 0.47-1.93 \\ \geq 728 & 29 & 39.7 & 96 & 43.8 & 0.82 & 0.82 & 0.42-1.63\end{array}$

Fruits

$\begin{array}{llllllll}0-156 & 25 & 34.2 & 64 & 29.2 & & 1.00 & \\ 157-363 & 12 & 16.4 & 48 & 21.9 & & 0.64 & 0.29-1.40 \\ \geq 364 & 36 & 49.3 & 107 & 48.9 & 0.53 & 0.86 & 0.47-1.56\end{array}$

Vegetables

$\begin{array}{llllllll}0-52 & 17 & 23.3 & 63 & 28.8 & & 1.00 & \\ 53-113 & 23 & 31.8 & 50 & 22.8 & & 1.70 & 0.82-3.53 \\ \geq 114 & 33 & 45.2 & 106 & 48.4 & 0.31 & 1.15 & 0.59-2.24\end{array}$

\section{Barbecue}

$\begin{array}{llllllll}0-11 & 22 & 30.1 & 72 & 32.9 & & 1.00 & \\ 12-27 & 26 & 35.6 & 71 & 32.4 & & 1.20 & 0.62-2.31 \\ \geq 28 & 25 & 34.2 & 76 & 34.7 & 0.8 & 1.08 & 0.56-2.08\end{array}$

Unless otherwise indicated, all intake frequencies are expressed in servings per year. The NA category was not considered for the regression model; it is included only to complete the data presented.

Salvo indicación, todas las frecuencias de consumo están expresadas en porciones por año. La categoría NA no fue considerada para el modelo de regresión; sólo aparece a efectos de completar los datos presentados. 
meat intake displayed non-significant differences, albeit this could be related to its low prevalence of consumption. The other foods analyzed did not show significant differences.

Several models, including all referred covariates, were tested using unconditional logistic regression analysis. Only variables related to "mate" consumption remained statistically significant after adjustment and were therefore included in the final model. Results of the best fitted model are displayed in Table 4. Cases tended to be more exposed than controls, regarding daily consumption in liters $(\mathrm{p}=0.04)$, duration in years $(\mathrm{p}=0.02)$, age that quit drinking "mate" $(\mathrm{p}=0.10)$ and intensity in liters per year $(p=0.03)$. These variables showed moderate positive associations to risk of esophageal cancer.

Table 5 shows the distribution of "Mate" Intensity by some socio-demographic vari- ables (education level, urban-rural status and region of birth).

\section{Discussion}

Our paper supports the hypothesis that a high consumption of "mate" increases the risk of esophageal cancer among non-smokers and non-drinkers.

Comparisons between crude and adjusted Odds Ratios for "mate" covariates revealed a consistent decrease for the latter, according to the relevant role of selected adjustment covariates.

The IARC monograph had classified hot "mate" drinking as probably carcinogenic to humans (group 2) and recommended, before reaching a more conclusive result, solving the following issues: a) recall bias (i.e. awareness that "mate" drinking may increase

Table 4 - Results of unconditional logistic regression model for "mate" related covariates (*).

Tabla 4 - Resultados del modelo de regresión logística incondicional para variables relacionadas con "mate" (*)

\begin{tabular}{|c|c|c|c|c|c|c|c|c|c|c|}
\hline Variable & Cases & $\%$ & Controls & $\%$ & CrudeOR & $95 \% \mathrm{Cl}$ & $\mathrm{p}$-value & Adjusted OR & $95 \% \mathrm{Cl}$ & $\mathrm{p}$-value \\
\hline \multicolumn{11}{|c|}{ Daily consumption (Its.) } \\
\hline $0-0.49$ & 11 & 15.1 & 67 & 30.6 & 1.00 & & & 1.00 & & \\
\hline $0.5-0.99$ & 23 & 31.5 & 68 & 31.1 & 2.06 & $(0.93-4.56)$ & & 1.60 & $(0.67-3.58)$ & \\
\hline$\geq 1$ & 39 & 53.4 & 84 & 38.4 & 2.83 & $(1.35-5.94)$ & 0.006 & 2.20 & $(1.02-4.91)$ & 0.044 \\
\hline \multicolumn{11}{|c|}{ Age quit "Mate" } \\
\hline$\leq 73$ & 34 & 46.6 & 125 & 57.1 & 1.00 & & & 1.00 & & \\
\hline $74-98$ & 35 & 47.9 & 78 & 35.6 & 1.65 & $(0.95-2.86)$ & 0.08 & 2.02 & $(0.87-4.70)$ & 0.10 \\
\hline N.A. & 4 & 5.5 & 16 & 7.3 & & & & & & \\
\hline \multicolumn{11}{|c|}{ Age started"Mate" } \\
\hline$\leq 13$ & 44 & 60.3 & 120 & 54.8 & 1.00 & & & 1.00 & & \\
\hline $14-98$ & 25 & 34.2 & 83 & 37.9 & 0.82 & $(0.47-1.45)$ & 0.49 & 0.74 & $(0.41-1.35)$ & 0.32 \\
\hline N.A. & 4 & 5.5 & 16 & 7.3 & & & & & & \\
\hline \multicolumn{11}{|c|}{ “Mate” duration (Yrs) } \\
\hline$\leq 60$ & 34 & 46.5 & 138 & 63.0 & 1.00 & & & 1.00 & & \\
\hline $61-98$ & 38 & 52.1 & 81 & 37.0 & 1.90 & $(1.11-3.31)$ & 0.02 & 2.49 & $(1.15-5.40)$ & 0.02 \\
\hline N.A. & 1 & 1.4 & 0 & 0 & & & & & & \\
\hline \multicolumn{11}{|c|}{ “Mate” intensity (Its.xYrs) } \\
\hline$\leq 36$ & 32 & 43.8 & 133 & 60.7 & 1.00 & & & 1.00 & & \\
\hline$\geq 37$ & 41 & 54.8 & 86 & 39.3 & 1.93 & $(1.13-3.31)$ & 0.02 & 1.91 & $(1.06-3.45)$ & 0.01 \\
\hline N.A. & 1 & 1.4 & 0 & 0 & & & & & & \\
\hline
\end{tabular}

(*) Adjusted for age, sex, education, urban/rural status and region of birth. / Ajustado por edad, sexo, educación, status urbano/rural y región de nacimiento. The category NA was not considered for the regression model; it is included only to complete the data presented. / La categoría NA no fue considerada para el modelo de regresión; sólo aparece a efectos de completar los datos presentados. 
Table 5 - Consumption of "Mate" according to socio-demographic variables (*).

Tabla 5 - Consumo de mate según variables sociodemográficas (*).

\begin{tabular}{lcccc}
\hline & \multicolumn{3}{c}{ Education (Yrs) } & p-value \\
"Mate" Intensity (Its x Yrs) & $0-2$ & $3-4$ & $5+$ & \\
$\leq 36$ & $41(24.8)$ & $48(29.1)$ & $76(46.1)$ & \\
$\geq 37$ & $44(34.9)$ & $46(36.5)$ & $36(28.6)$ & 0.01 \\
& & & \\
& & Birth region & \\
"Mate" Intensity (Its x Yrs) & South & Center & North & \\
$\leq 36$ & $58(35.1)$ & $60(36.4)$ & $47(28.5)$ & 0.001 \\
$\geq 37$ & $25(19.8)$ & $72(57.1)$ & $29(23.1)$ & \\
& \multicolumn{3}{c}{ Urban/Rural Status } \\
"Mate" Intensity (Its x Yrs) & Urban & Rural & \\
$\leq 36$ & $134(81.2)$ & $31(18.8)$ & 0.02 \\
$\geq 37$ & $88(69.8)$ & $38(30.2)$ & \\
\hline
\end{tabular}

(*) One case classified as NA for "Mate" intensity has been excluded. / Se excluyó un caso clasificado como NA en la intensidad de "mate".

the risk for cancer could have led to increased reporting of "mate" drinking for cancer cases as compared with controls); b) confirmation of the mate-cancer relationship by other groups of investigators; and c) exclusion of the possibility of residual confounding by tobacco smoking and alcohol drinking ${ }^{17}$. In order to avoid this residual confounding, our study population was restricted to nondrinkers and non-smokers.

Concerning recall bias, differential reporting by cases and controls is not likely in the present study, because no association between risk of esophageal cancer and "mate" drinking has been reported to date. On the contrary, the consumption of "mate" is popularly considered as a healthy infusion.

As in developed countries, high consumption of alcohol and of tobacco are the major risk factors for esophageal cancer in Uruguay $^{18,19}$. Low fruit and vegetable intake has also been shown as a strong risk factor ${ }^{20}$. The anti-carcinogenic factors found in those foods include ascorbic acid, vitamin E, carotenoids, flavonoids, phytosterols, indoles, fiber, among others ${ }^{21}$. Moreover, a larger consumption of vegetables and fruits may be an expression of a more generally healthy attitude towards diet and other lifestyle habits.

Uruguay is a country with recognized regional differences, concerning the spatial distribution of poverty ${ }^{22}$. The Southern and Southwestern regions are more developed; an ascending gradient of poverty is found when moving towards the North and Northeastern areas. The most critical situation is found for the political regions on the border with Brazil (our Region labeled "North"), where most people have one or more "unsatisfied basic need" (access to drinking water, to healthcare systems, to electricity, etc), that is, where living conditions are notably worse than in other zones of the country ${ }^{23}$. Related to these facts, Table 5 shows that a lower consumption of "Mate" is associated with higher levels of education, urban status and southern birth regions.

Taking into account that case-control matching was based on age and sex categories, patients were characterized mainly by low income, a low sociocultural level and affiliation to the public healthcare system. In addition, given that the urban/rural status was not statistically different between cases and controls, we also considered the control group analyzed as acceptable, considering the small sample of cancer cases that met both conditions (non-smokers and non-drinkers). It would have been desirable to have enough available control patients coming from the same regions of residence of cases, but this was not feasible from a practical viewpoint, 
due to the nature and number of patients admitted at the study institution, and we recognize this limitation for the present analysis. At any rate, regression models included these terms in adjustments, in order to avoid confusion as much as possible.

Furthermore, Uruguay has the highest per capita meat intake in the world ${ }^{24}$. The lower socioeconomic strata of the Uruguayan population are also high red meat consumers, as a consequence of the relatively low domestic prices and high availability of this primary product of Uruguay. Therefore, meat consumption is not an indirect indicator of wealth status. Anyhow, the existence of other not analyzed potential risk factors which could be related to esophageal cancer cannot be precluded in the present paper.

The increased OR's observed in digestive cancers have been attributed to thermal injury resulting from the hot temperature at which certain beverages ("mate", tea) are usually drunk ${ }^{5,17,25}$, albeit other experiments have focused on chemical injury ${ }^{17}$.

Experiments at the cellular level combining exposure of "mate" and hyperthermia have not found mutagenic activity due to "mate" infusion, and the highest observed mutagenic rate corresponded to hyperther$\mathrm{mia}^{25}$. A few years ago an international panel of experts recognized that "mate" possibly increases the risk of esophageal cancer because of the temperature at which it is consumed $^{26}$.
The genotoxic activity of "mate" infusions in short-term tests has been also reported ${ }^{27}$. Several analyses performed with "mate" have identified several substances in it, such as caffeine, theobromin, clorogenic and ascorbic acid, among others ${ }^{17}$. Of particular interest were the large amounts of benzopyrene found in several brands of "mate" ${ }^{17}$. In the only experimental study in animals performed to date, the use of tar from the "mate" leaf processing applied to the skin induced skin carcinoma ${ }^{28}$. Caffeic acid, a clorogenic and isoclorogenic acid precursor, is present in "mate" and has been considered as a possible carcinogen in humans ${ }^{29}$. Therefore, a series of chemicals present in "mate" (i.e. caffeic acid, benzopyrene) could be responsible for the increased risks of esophageal cancer. Taking into account that Uruguayan inhabitants have an average annual consumption of 8 kilograms of Ilex paraguariensis (i.e. 45 milligrams of benzopyrene/year) ${ }^{5}$, an increased risk of cancer is biologically plausible.

In summary, this paper shows that "mate" is an independent risk factor for esophageal cancer, contributing to exclude the role of residual confounding due to alcohol and tobacco consumption, according to the above quoted IARC's recommendation. The underlying mechanism, whether thermal injury and/or chemical carcinogenicity, still remains unclear. The conclusive role of low intake of vegetable and fruits also deserves further investigation.

\section{References}

1. Parkin DM, Whelan SL, Ferlay J, Raymond L, Young J (eds.). Cancer Incidence in five continents Vol.VII. IARC Sci. Publ. No143, Lyon: International Agency for Research on Cancer; 1997.

2. Vassallo JA, Barrios E, De Stéfani E, Ronco AL. II Atlas of Cancer Incidence in Uruguay 1996-1997. Montevideo: Comisión Honoraria de Lucha Contra el Cáncer; 2001. (in Spanish)

3. Comisión Honoraria de Lucha contra el Cáncer. Knowledge, believes, attitude and practices concerning cancer. Montevideo: Comisión Honoraria de Lucha contra el Cancer; 1993. (in Spanish)
4. De Stéfani E, Barrios E, Fierro L. Black (air-cured) and blond (flue-cured) tobacco and cancer risk: oesophageal cancer. Eur J Cancer 1993; 29(5): 763-6.

5. De Stéfani E, Muñoz N, Estève J, Vassallo A, Victora C, Teuchmann S. Maté drinking, alcohol, tobacco, diet and esophageal cancer in Uruguay. Cancer Res 1990; 50: $426-31$.

6. Vassallo A, De Stéfani E, Correa P, Cendan M, Zavala D, Chen V et al. Esophageal cancer in Uruguay. A casecontrol study. J Natl Cancer Inst 1985; 75:1005-9. 
7. De Stéfani E, Correa P, Oreggia F, Leiva J, Rivero S, Fernández G et al. Risk Factors for Laryngeal Cancer. Cancer 1987; 60: 3087-91.

8. De Stefani E, Correa P, Oreggia F, Deneo-Pellegrini H, Fernandez G, Zavala D et al. Black tobacco, wine and mate in oropharyngeal cancer. Rev Epidemiol Santé Publ 1988; 36: 389-94.

9. De Stéfani E, Correa P, Fierro L, Fontham E, Chen V, Zavala D. Black Tobacco, Mate and Bladder Cancer. A Case Control Study from Uruguay. Cancer 1991; 67: 536-40.

10. La Vecchia C, Negri E. The role of alcohol in oesophageal cancer in non-smokers, and of tobacco in non-drinkers. Int J Cancer 1989; 43: 784-85.

11. Tavani A, Negri E, Franceschi S, La Vecchia C. Risk factors for esophageal cancer in lifelong non-smokers. Cancer Epidemiol Biomarkers \& Prevention 1994; 3: 387-92.

12. Tuyns AJ. Oesophageal cancer in non-smoking drinkers and in non-drinking smokers. Int J Cancer 1983; 32: 443-4.

13. Willett W. Nutritional Epidemiology. New York: Oxford University Press; 1990. p 92-126.

14. Mantel N, Haenszel W. Statistical aspects of the analysis of data from retrospective studies of disease. $J$ Natl Cancer Inst 1959; 22: 719-48.

15. Breslow NE, Day NE. Statistical methods in cancer research. Vol. I.: The analysis of case-control studies. IARC Sci. Publ. No 32. Lyon: International Agency for Research on Cancer; 1980.

16. STATA. STATA user's guide and reference manual, Release 6. College Station, Texas: STATA Press; 1999.

17. IARC. Coffee, tea, mate, methylxanthines and methylglyoxal. Monographs on the evaluation of the carcinogenic risk of chemicals to humans, vol. 51. Lyon: International Agency for Research on Cancer; 1991.

18. Muir CS, McKinney PA. Cancer of the oesophagus: a global overview. Eur J Cancer Prev 1992; 1: 259-64.
19. Tuyns AJ. Alcohol and cancer. An instructive association. Br J Cancer 1991; 64: 415-6.

20. De Stéfani E, Oreggia F, Boffetta P, Deneo-Pellegrini H, Ronco A, Mendilaharsu M. Tomatoes, tomato-rich foods, lycopene and cancer of the upper aerodigestive tract: a case-control in Uruguay. Oral Oncol 2000; 36(1): 47-53.

21. World Cancer Research Fund. Food, Nutrition and the prevention of cancer: a global perspective. Washington DC: World Cancer Research Fund; 1997. p. 125.

22. Pellegrino A, González S. Demographic Atlas of Uruguay. Montevideo: Ed. Fin de Siglo; 1995. (in Spanish)

23. Calvo JJ. The unsatisfied basic needs in Uruguay. Montevideo: Ed. School of Social Sciences, University of the Republic; 2000. (in Spanish)

24. Food Agriculture Organization. Food Balance Sheets 1999. Rome: FAO; 1999.

25. Candreva EC, Keszenman DJ, Barrios E, Gelós U, Nunes E. Mutagenicity Induced by hyperthermia, hot mate infusion, and hot caffeine in Saccharomyces cerevisiae. Cancer Res 1993; 53: 5750-3.

26. World Cancer Research Fund. Food, nutrition and the prevention of cancer: a global perspective. Washington DC: World Cancer Research Fund; 1997. p.128.

27. Leitão AG, Braga RS, Fonseca CAS. Genotoxicity of natural products (studies with mate and guarana). $J$ Braz Soc Toxicol 1991; 4: 35.

28. Roffo AH. Cancer producido por el alquitrán del mate. Bol Inst Med Expt Cancer 1941; 18(56): 5-20.

29. IARC. Some naturally occurring substances. Monographs on the evaluation of the carcinogenic risk of chemicals to humans, vol. 10. Lyon: International Agency for Research on Cancer; 1976.

recebido em: 12/07/2004 versão final apresentada em: 08/11/2004 aprovado em: 11/11/2004 